\title{
O FORMALISMO JURÍDICO, A EDUCAÇÃO JURÍDICA E A PRÁTICA PROFISSIONAL DO DIREITO NA AMÉRICA LATINA*
}

\author{
THE LEGAL FORMALISM, LEGAL EDUCATION AND PROFESSIONAL PRACTICE OF \\ LAW IN LATIN AMERICA
}

Daniel Eduardo Bonilla Maldonado ${ }^{* *}$

\begin{abstract}
Resumo
Na América Latina, predomina o modelo formalista de ensino jurídico e concepção do direito, que o idealiza como emanação exclusiva da legislação e conjunto de normas piramildamente escalonado e mecanicamente aplicável, sem conjeturas acerca de sua moralidade, ensinado nas faculdades por meio de exposição teórica do conteúdo legal. Este artigo pretende descrever os defeitos do formalismo jurídico e propor a criação e efetivação de núcleos de prática de interesse público, para aprimoramento do aprendizado jurídico e construção de um novo conceito do direito na América Latina, a partir da experiência de imersão social proporcionada pela vivência dos casos práticas na formação jurídica.
\end{abstract}

Palavras-chave: Formalismo. Núcleos de Prática. Interesse Público. Educação jurídica. América Latina.

\begin{abstract}
In Latin America, the predominant formalist model of legal education and conception of law, that idealizes it only as an emanation of legislation and as set of rules staggered in pyramidal shape and mechanically applied, without guesswork about its morality, and taught in colleges by theoretical exposure of the content of legislation. This scientific article describes the shortcomings of legal formalism and proposes the creation and effective activity of centers of public interest for legal practice, for the improvement of legal learning and building a new concept of law in Latin America, from the experience of social immersion provided by of practical training in legal cases.
\end{abstract}

Keywords: Formalism. Center of legal practice. Public interest. Legal education. Latin America.

\section{Introdução}

Os "núcleos de prática jurídica de interesse público" na Améria Latina são um instrumento poderoso para questionar e debilitar o formalismo que tem dominado a cultura jurídica da região. Estas iniciativas são, também, uma ferramenta potente para debilitar as

\footnotetext{
* Artigo traduzido do original em espanhol (El Formalismo Jurídico, la Educación Jurídica y la Práctica Profesional del Derecho en Latinoamérica) para português por Alexandrina Benjamin Estevão de Farias. Revisão e abstract por Wendel Rosa Borges.

** Professor Associado de Direito Público e Constitucional da Universidad de los Andes. Autor dos livros "Constitutionalism of the Global South: The Activist Tribunals of India, South Africa, and Colombia". Cambridge University Press (2013). (ISBN 978-110-703-621-5) e "Función Social de la Propiedad". Eudeba, 2013. (ISBN 9789502321615). dbonilla@uniandes.edu.co.
} 
bases da educação jurídica e da prática profissional formalista fortemente arraigada nesta zona do continente americano. O conceito de direito formalista identifica o sistema jurídico como a lei; considera que o direito é completo, coerente e fechado; assinala que este é capaz de dar respostas únicas a todos os problemas que surgem em uma comunidade política; e, em versões extremas nivela validez formal com justiça. De igual forma, este conceito de direito se entrecruza com uma interpretação clássica da democracia liberal que promove uma separação radical entre os ramos do poder público. Consequentemente, o legislador é o único que tem capacidade criadora de direito, os juízes devem, e podem, ser neutros e a tarefa primordial do executivo é a materialização das normas jurídicas preexistentes.

A educação jurídica formalista, que reforça e reproduz o conceito de direito formalista, gira em torno ao enciclopedismo curricular, a memorização e o conceitualismo. Promove currículos com um alto número de matérias de maneira que os estudantes conheçam todas as criações do legislador, considera que conhecer o direito é diretamente proporcional à capacidade de repetir o texto da lei, e afirma que o ensino do direito deve girar em torno de categorias abstratas, princípios e regras, e de suas relações formais e substanciais. Para essa perspectiva da educação não são relevantes as perguntas pela legitimidade moral e política das normas e instituições jurídicas, separa a dogmática da teoria e prática jurídica, isola o direito privado do direito público, e tem como único método de ensino a classe magistral. A educação jurídica formalista, por conseguinte, gira em torno dos materiais criados pelo legislador, pretende que os estudantes os conheçam em sua totalidade e que os reproduzam acriticamente, promove um currículo em que as distintas áreas do direito se mantenham isoladas e situa o professor no centro do processo de ensino-aprendizagem.

Este tipo de educação gera um profissional do direito com características particulares e problemáticas. Os advogados educados nas faculdades de direito formalistas tendem a considerar que possuem uma e somente uma obrigação profissional: representar competente e eticamente a seus clientes. Os advogados não possuem deveres para com a comunidade na que se encontram imersos. Igualmente, os advogados formalistas, especialmente os recém-graduados, se enfrentam com sérias dificuldades para pôr em prática o arsenal de categorias jurídicas aprendidas na universidade. Paradoxalmente, dado o caráter profissionalizante das faculdades de direito formalistas, uma vez que entram no mercado laboral, os jovens advogados evidenciam que embora conheçam os materiais jurídicos com relativa competência, não têm desenvolvido ou consolidado as destrezas necessárias para 
atuar competentemente na prática profissional. Por exemplo, não sabem como redigir um memorial, entrevistar um cliente ou avaliar as possíveis consequências de optar por uma ou outra estratégia jurídica em um caso particular. Agora, os núcleos que existem nas faculdades de direito latino-americanas têm aberto espaço importante para cumprir três fins que explicitamente questionam a teoria e a prática formalista que domina nossa imaginação política e jurídica. Por um lado, têm como objetivo fazer uso do direito como um instrumento de mudança social. Para os núcleos latino-americanos dimana fundamental contribuir, fazendo uso do direito, para a construção de sociedades mais livres, solidárias e igualitárias. Por outro lado, os núcleos latino-americanos pretendem que a educação experimental se torne um componente importante da educação jurídica na região. Os estudantes do direito devem aprender "fazendo", não unicamente através da leitura de documentos e da assimilação das palavras pronunciadas pelo professor na sala de aula. Os alunos devem aprender diante de tarefas que são típicas na comunidade jurídica sob a supervisão constante de um professor. Finalmente, os núcleos buscam que os estudantes desenvolvam ou consolidem destrezas fundamentais para chegar a ser profissionais competentes e socialmente responsáveis. A educação jurídica não deve se centrar somente na informação e não deve formar advogados competentes a partir do ponto de vista profissional, mas que consideram que suas responsabilidades morais se encerram com a satisfação das necessidades e exigências de seus clientes.

Contudo, é preciso destacar que a luta contra o formalismo jurídico que tem alcançado os núcleos de prática jurídica de interesses públicos latino-americanos não tem cumprido seu objetivo totalmente. Obstáculos políticos, econômicos e acadêmicos que se entrecruzam na prática e que surgem dentro e fora das faculdades de direito têm impedido que assim seja. No eixo político, os impedimentos mais importantes referem-se à oposição que este tipo de projeto gera entre alguns setores conservadores dos professores e da administração da universidade. Esta oposição política impede que os núcleos, por exemplo, obtenham uma porção justa dos recursos econômicos disponíveis para financiar suas atividades, dificulta que seus projetos sejam aceitos ou que se avance com fluidez casos complexos que afetam de modo negativo setores poderosos da sociedade, ou desestimula a criação de novos espaços de educação jurídica prática dentro das faculdades.

No eixo econômico, os professores do núcleo muitas vezes se encontram com o fato de que, apesar de existir vontade política para criar ou fortalecer projetos de educação 
jurídica prática, não existem suficientes recursos econômicos para fazê-lo adequadamente. Não existe dinheiro suficiente, entre outras coisas, para contratar professores de dedicação exclusiva que possam dirigir ou supervisionar este tipo de projeto ou para financiar a infraestrutura necessária para que estes possam florescer e expandir-se.

No eixo acadêmico, os professores do núcleo enfrentam a rigidez dos programas curriculares, o que dificulta a criação de matérias práticas, ou a lentidão das burocracias universitárias competentes para transformá-los. De igual forma, os professores do núcleo enfrentam a desordem que geram alguns de seus produtos quando devem ser avaliados institucionalmente. Não é claro qual é o valor que se deve atribuir a uma demanda, um informe de direitos humanos ou uma cartilha que explica de maneira simples os direitos que tem um grupo vulnerável da população. De igual maneira, muitos núcleos de prática jurídica de interesse público da região enfrentam o desinteresse de amplos setores dos estudantes. Estes programas, afirma-se geralmente, não contribuem para alcançar seu objetivo primordial, isto é, entrar rapidamente na prática profissional privada ou nos quadros da burocracia estatal.

Agora, os obstáculos não são somente externos. Alguns projetos de núcleos não obtêm sucesso em sua consolidação pela falta de clareza e precisão de seus fins ou pela ausência de uma reflexão crítica, complexa e sustentada que descreva e avalie o trabalho realizado e ofereça horizontes normativos para guiar os planos que se avançaram no futuro.

Este artigo tem como objetivo desenvolver e justificar os argumentos anteriormente apresentados. Para cumprir este fim, o texto se divide em quatro partes: na primeira, apresentarei a coluna vertebral do formalismo jurídico latino-americano e mostrarei como que os núcleos são uma ferramenta poderosa para fragilizar o conceito de direito que tem sido dominante na prática e na teoria jurídica da região. Não argumento que o formalismo seja, o que tem sido, o único conceito de direito existente na latino-américa. Pelo contrário, o positivismo, a escola livre do direito e a teoria sociológica do direito, entre outros conceitos alternativos, também tem influenciado na maneira como os latino-americanos entendem o direito. Contudo, estes conceitos de direito não têm tido o mesmo impacto que o formalismo na definição do marco dentro do qual os latino-americanos pensam assuntos jurídicos básicos. O formalismo tem dominado, e, todavia domina boa parte da imaginação jurídica latinoamericana, resistindo aos ataques que tem recebido desde muitas frentes. A jurisprudência da Corte Constitucional colombiana e as publicações de muitos membros da academia do direito 
não formalistas, por exemplo, não têm sido suficientes para mandar o formalismo para as margens de nossa imaginação jurídica. Os esforços de faculdades de direito, como as da Universidade de Los Andes, Getulio Vargas, ITAM e Diego Portales, por nomear algumas, tampouco têm sido efetivos para alcançar este objetivo. O formalismo ainda tem uma presença forte na educação jurídica latino-americana, em geral, e em particular, nas faculdades que têm como projeto normativo questioná-lo e deixá-lo de lado.

Nesta primeira seção, tampouco argumento que não devemos tomarmos em sério o direito latino-americano. $\mathrm{O}$ fato de que o formalismo tenha sido central para entender e aplicar o direito na região não significa que devamos esquecer o direito e concentrarmos na política para entender a Latino- América. Tão pouco quer dizer que devemos aproximar-nos ao direito através de uma perspectiva sociológica que trata de explicar seu fracasso. O direito certamente desempenha, e tem desempenhado um papel importante nas comunidades políticas latino-americanas. Ainda mais, o direito, como o demonstra o trabalho de muitos núcleos da região, certamente poder ser usado para alcançar importantes objetivos emancipatórios. $\mathrm{O}$ direito tem sido e pode ser uma ferramenta poderosa para a mudança social na região.

$\mathrm{Na}$ segunda parte deste artigo examinarei a educação jurídica e a prática profissional formalista e na terceira analisarei as características da educação jurídica aplicada nos núcleos em América Latina. Nesta apresentarei os principais obstáculos que tem impedido a criação e/ou consolidação de núcleos de prática jurídica de interesse público na região e que tem feito que este instrumento não tenha sido tão efetivo como seria desejável na luta contra o formalismo jurídico. Na quarta parte, oferecerei de maneira muito breve, algumas estratégias que contribuíram para a criação e/ou consolidação dos núcleos de prática jurídica de interesse público na América Latina. Estas recomendações, por tanto, ajudariam que os projetos de educação jurídica sejam muito mais eficientes em seu questionamento do formalismo jurídico.

O texto, portanto, entrelaça teoria e prática. Pretende contribuir à compreensão e avaliação do conceito de direito dominante na América Latina e sua relação com a educação jurídica aplicada nos núcleos, mas também pretende precisar os principais obstáculos que dificultam a criação ou consolidação de núcleos de prática jurídica na região e apresentar algumas sugestões concretas sobre como superá-los. Desta maneira, os objetivos que persegue o texto são de distintos tipos, ainda que complementários. Por um lado, busca apresentar ao 
leitor não especializado alguns problemas e discussões teóricas que são bem conhecidas em círculos especializados. O conceito de direito formalista e seu impacto na educação jurídica e a prática profissional são temas que têm sido trabalhados pela teoria do direito hispanoamericano. Meu propósito, em relação com este ponto, é expor de maneira completa, clara e simples as coordenadas que estruturam esta discussão. Por outro lado, o escrito pretende conectar estas discussões teóricas com a educação jurídica prática, uma ponte que tem sido pouco explorada até agora. Finalmente, gostaria de oferecer uma rota básica, mas quiçá efetiva, que possa contribuir para a criação ou consolidação de projetos de educação jurídica nos núcleos na região.

\section{0 marco teórico dos núcleos de prática jurídica de interesse público latino-americano}

O conceito de direito, a noção de educação jurídica e a prática profissional do direito são três categorias que estão entrelaçadas teórica e praticamente. Mudanças em uma delas implicam em alterações nas outras duas. Assim, por exemplo, o surgimento de um novo campo para a prática profissional pode gerar transformações no currículo e/ou no conceito de direito dominante. $\mathrm{O}$ nascimento do direito do entretenimento, dos esportes ou a resolução alternativa de conflitos, seguindo com os exemplos, tem feito que muitas faculdades abram espaços para estes temas em seus currículos. Estas decisões acadêmicas muitas vezes trazem como consequência a eliminação de outras matérias e, portanto, interpretações sobre quais áreas do direito são importantes ou que se devem ensinar em uma faculdade. Essas mudanças no currículo, contudo, geralmente não têm consequências sobre o conceito de direito dominante. Estas transformações usualmente não são estruturais, senão variações dentro dos limites impostos pelo conceito de direito que prevalece na comunidade jurídica. Não obstante, em outros casos, como o direito de interesse público na América Latina, a situação parece distinta. A presença desta nova matéria nas faculdades tem conseguido mudanças curriculares menores, mas também tem logrado corroer algumas das bases sobre as quais se sustenta o conceito de direito formalista que domina a consciência jurídica latino-americana.

Agora, apesar de sua contínua interação e mútua transformação, o conceito de direito que se defende tem preeminência analítica e prática sobre as outras duas categorias: educação jurídica e prática profissional. Os distintos conceitos de direito nos indicam quais são os elementos estruturais dos ordenamentos jurídicos, os fins que estes devem perseguir ou os papéis que os distintos operadores jurídicos - advogados, juízes e legisladores, entre outros 
-, devem interpretar na prática jurídica. Assim, por exemplo, o positivismo jurídico contemporâneo se concentra na descrição e na análise das regras primárias e secundárias que se consideram a coluna vertebral de um ordenamento jurídico nacional e o funcionalismo nos objetivos que têm o direito nas sociedades: justiça, ordem ou opressão, por exemplo. Estas perspectivas, a sua vez condicionam a maneira em que se pensa e desenvolve a educação jurídica e a prática profissional. Desta forma, por exemplo, a preeminência de um conceito funcionalista do direito em uma determinada faculdade teria como consequência muito segura a articulação de um currículo interdisciplinar, isto é, um programa que inclui um número notável de matérias que vêm das ciências sociais e uma aproximação multidisciplinar aos temas jurídicos tradicionais.

Desta forma, os programas nas faculdades de direito e as metodologias para seu ensino se articulam em torno do conceito de direito que tem-se tornado hegemônico na comunidade jurídica e política particular. O fim principal da educação não é outro que reproduzir nas novas gerações o conceito de direito que tem conquistado a consciência dos cidadãos. De igual forma, a educação que se ministra determina as características centrais da prática jurídica. Os jovens advogados atuarão na vida profissional guiada pelas categorias conceituais aprendidas na universidade e tentarão satisfazer as exigências normativas impostas aos papéis que podem encarnar na prática, tais como advogados, juízes e legisladores. Os juízes colombianos ou mexicanos, por exemplo, tentarão atuar de maneira que suas decisões reflitam o valor da neutralidade que defende o formalismo jurídico. O juiz de uma comunidade em que o conceito de direito defendido pela análise econômica do direito se tenha tornado hegemônico tentará, pelo contrário, que suas decisões sejam eficientes e, assim, terá em conta as consequências econômicas que estas podem gerar.

Na América Latina, desde o século XIX até hoje o conceito de direito hegemônico tem sido o formalismo jurídico. Este conceito de direito, como se verá mais a frente, é consequência do entrecruzamento e apropriação na região de algumas das premissas fundamentais defendidas pela escola da exegese francesa e pelo historicismo alemão. Uma das características fundamentais do formalismo jurídico latino-americano é que identifica o direito com a lei. Desta maneira, pra o formalismo, a unidade central de qualquer ordenamento jurídico é o conjunto de normas criadas pelo legislador. Assim, outras fontes criadoras de direito como a jurisprudência, os princípios gerais de direito que não tenham sido positivados e a doutrina, se consideram secundárias e podem usar-se unicamente quando não 
haja uma lei específica que regule a matéria que se pretende controlar, ou quando as leis existentes não sejam claras ou precisas. O formalismo, portanto, está comprometido com uma forma particular de entender o sistema de fontes criadoras de direitos em uma comunidade política. Nesta interpretação, a lei se considera a fonte suprema.

Na Colômbia, por exemplo, esta premissa tem gerado uma disputa jurídica e política de grande envergadura entre a Corte Constitucional e a Corte Suprema de Justiça. A primeira, tem defendido uma interpretação do sistema de fontes consagrado na Constituição de 1991 que indica que a jurisprudência tem o mesmo valor que a lei como fonte criadora de direito. Este argumento lhe tem servido à Corte Constitucional para fundamentar a obrigatoriedade do precedente na Colômbia, tanto o constitucional como o da justiça ordinária e da administrativa. A Corte Suprema de Justiça tem indicado que a tradição jurídica civilista à que pertence Colômbia está comprometida com o caráter supremo da lei. Os juízes, consequentemente, e como o indica de maneira clara o artigo 230 da carta política de 1991, "somente estão submetidos ao império da lei". A jurisprudência, acrescenta a Corte Suprema, é unicamente uma fonte secundária optativa para o juiz, que somente opera quando se evidencia um vazio legal ou quando a lei é lacunosa ou ambígua.

Em segundo lugar, o formalismo considera que o ordenamento jurídico é um sistema completo. O direito, portanto, é um conjunto hierarquizado de normas jurídicas, principalmente leis, que oferece respostas para todos os conflitos que possam surgir em uma sociedade. Neste sentido, o direito não tem lacunas. Isto não significa que o direito inclua uma lei específica para regular cada uma das práticas sociais existentes ou futuras. Significa, melhor dizendo, que em caso de que não haja uma regra que controle o caso sob estudo, o direito fornece ferramentas alternativas para solucioná-lo, por exemplo, métodos de interpretação, como a analogia y normas jurídicas gerais como os princípios. A primeira ferramenta permitirá aplicar uma lei que regule um caso similar ao que se pretende resolver; a segunda, decidir uma controvérsia apelando às normas jurídicas que justificam o sistema jurídico - ou uma área específica do mesmo - e que têm um alto nível de abstração, o que permite sua aplicação a diversas situações fáticas.

Em terceira instância, o formalismo jurídico argumenta que o direito é um sistema fechado. $\mathrm{O}$ direito, a partir desta perspectiva, é um conjunto autônomo de normas jurídicas. $\mathrm{O}$ sistema tem seus próprios mecanismos para criar, aplicar, modificar e destruir as unidades que 
o compõem. Não necessita de nenhum outro sistema para substituir e reproduzir-se. O direito não tem e não deve construir pontes que o comuniquem com outros sistemas, por exemplo, a sociologia ou a psicologia. Fazê-lo, contaminaria o direito com agentes estranhos que respondem a uma lógica interna distinta e que podem levar a que o direito se desnaturalize ou funcione inadequadamente.

Em quarta instância, o formalismo afirma que o direito é coerente. Desta maneira, o direito se entende como um sistema onde seus componentes não se contradizem. As normas jurídicas têm uma relação harmônica entre si como consequência da sabedoria do legislador e do caráter hierarquizado do sistema, o qual se representa paradigmaticamente na pirâmide kelseniana. O formalismo aceita que ocasionalmente o legislador possa falhar e expedir normas contraditórias. Contudo, nestes casos, o ordenamento jurídico oferece uma série de ferramentas para a interpretação e aplicação de normas que permite que o operador jurídico solucione as discordâncias criadas pelo Congresso. Assim, por exemplo, o formalismo afirma que regras como as que indicam que a norma posterior deve aplicar-se sobre a regra anterior, a específica sobre a geral e a superior sobre a inferior, proporciona os instrumentos para solucionar as antinomias que aparecem de quando em quando em um sistema jurídico.

Em quinta instância, o conceito formalista do direito afirma que este fornece respostas unívocas para as matérias e conflitos sociais que regula. A claridade e a precisão com a que o legislador, que se presume sábio, redige as leis garante a univocidade de seus mandatos. Como consequência, o interprete deve, como regra geral, ser fiel ao texto da lei. Nas palavras escolhidas pelo legislador se expressa sua vontade, a qual, também se presume, não é outra coisa que a vontade da cidadania que representa. Consequentemente, o formalismo considera a exegese como o método mais apropriado para a interpretação da lei, contudo, aceita que ocasionalmente esta possa ser obscura. O legislador, enquanto ser humano, falha de vez em quando. Não obstante, nestes casos, o direito, também lhe oferece alternativas ao operador jurídico. Em primeiro lugar, o formalismo lhe oferece o método teleológico de interpretação. O indivíduo deve participar da intenção do legislador para solucionar os problemas que geraram as normas vagas ou ambíguas. O operador deve especificar os objetivos que o legislador teve ao promulgar a lei, apelando às exposições de motivos e as atas que registram os debates dos legisladores que antecederam a aprovação das normas jurídicas cujo mandato não é claro e preciso. Em caso de que este método não gere uma resposta satisfatória, sem segundo lugar, o operador jurídico, deve usar outros métodos 
de interpretação como a analogia ou o sistemático. Deve, portanto, fazer uso de normas que regulamentam matérias similares às que regula as normas obscuras ou apelar a outros princípios ou regras do sistema para articular uma interpretação de conjunto que dê sentido à norma lacunosa ou ambígua.

Em sexta instância, o formalismo jurídico, com a ajuda de uma interpretação clássica da democracia liberal, defende o princípio de separação radical dos três ramos do poder público. O formalismo considera que o único que tem capacidade criadora do direito é o legislador, enquanto que somente ele representa os cidadãos e só ele pode gerar obrigações e direitos que limitem a liberdade das pessoas e determinem como hão de solucionar-se os conflitos que surjam entre elas. Da mesma maneira, considera que o juiz tem como tarefa solucionar os conflitos particulares através da aplicação do direito preexistente. Os juízes não devem criar direitos enquanto não tenham legitimidade democrática direta. Os juízes não são, por regra geral, eleitos pelos cidadãos. Para o formalismo, o juiz deve, e pode ser, neutro. Não deve envolver seus compromissos morais e políticos na solução dos conflitos que enfrenta diariamente como autoridade pública.

Finalmente, o ramo executivo tem como tarefa fundamental a aplicação dos mandados criados pelo legislador. Essa obrigação não se refere à solução de conflitos particulares que é a tarefa dos juízes. Trata-se de uma aplicação sustentada e sistemática das normas criadas pelo legislador nas distintas esferas que compõem uma sociedade.

Esta separação funcional acentuada entre os ramos do poder público choca com outras interpretações do princípio liberal de separação de poderes. O formalismo rivaliza com duas interpretações amplamente aceitas hoje em dia sobre este princípio. De um lado, aquela que indica que um Estado contemporâneo só pode funcionar adequadamente se os ramos do poder público não somam de maneira contínua funções que historicamente tem sido consideradas como próprias de outros ramos. De fato, se soma, na prática, isto vem sucedendo sem sobressaltos desde há muitos anos. As agências administrativas comumente resolvem casos particulares e penalizam os cidadãos, os congressos incluem comitês que investigam e castigam funcionários públicos e os juízes, em ocasiões, criam direito. De outro lado, a interpretação em que incorre o formalismo jurídico sobre o princípio de separação de poderes contrasta com aquela que promove a cooperação harmônica dos poderes públicos. Para que um Estado possa cumprir apropriadamente com seus objetivos se argumenta que é necessária 
a existência de um diálogo constante, uma interação contínua entre o executivo, o legislativo e o judiciário.

Em sétima e última instância, o formalismo em suas versões extremas identifica validade formal com justiça. Os formalistas radicais consideram que uma norma jurídica que haja sido criada pela instituição competente e seguindo os procedimentos preexistentes para gerar direito deve ser considerada justa. Embora a expressão seja de quem tem poder criador de direitos em uma comunidade particular, seus conteúdos se devem aceitar como justos. A legitimidade democrática de que goza o legislador permite presumir que os conteúdos da lei estão política ou moralmente fundamentados. Os procedimentos para a expedição de uma norma também garantem que outros valores com os quais está comprometida a comunidade, como a participação apropriada de minorias e maiorias no debate legislativo ou a não intervenção indevida de indivíduos ou organizações privadas econômicas ou socialmente poderosas no processo de criação da lei, sejam adequadamente protegidos.

Como se pode ver, a cultura jurídica latino-americana, fundamentalmente formalista, se encontra ancorada no século XIX europeu. As conexões estreitas entre o formalismo latino-americano e a escola da exegese francesa e o historicismo alemão saltam à vista. Por um lado, o formalismo está comprometido com uma interpretação do século dezenove do liberalismo político e jurídico. Tal interpretação de cânon liberal se estrutura em torno de dois eixos: o princípio da separação de poderes e o princípio de separação entre o direito e a política. Estes dois princípios, que se reforçam e complementam, partem de uma premissa comum: uma coisa é o processo político de criação do direito de onde as distintas forças que compõem a sociedade se enfrentam e chegam a uma solução acordada ou imposta, e outra, a aplicação do direito de onde os operadores jurídicos com autoridade, especialmente os juízes, devem fazer um uso neutro de normas preexistentes para solucionar conflitos particulares. Estes dois princípios são fundamentais para evitar a excessiva concentração de poder em uma instituição e, portanto, para conter qualquer intenção de impor um governo tirânico. De igual forma, são centrais para lograr o balanço adequado entre dois valores fundamentais do projeto moderno iluminista e liberal: razão e vontade.

A partir da perspectiva do liberalismo político e jurídico novecentista francês, o legislador é quem expressa à vontade do povo soberano. Portanto, quando cria direito, deve honrar as preferências daqueles que o elegeram. Não obstante, ao mesmo tempo, deve fazer 
uso da razão para criar normas jurídicas claras, precisas, justas, universais e atemporais. A razão, entendida como a ferramenta que nos pode levar à verdade absoluta, deve limitar a vontade. A tensão entre a razão e a vontade se faz evidente. Para que o legislador seja legítimo deve ser eleito democraticamente e representar a voz de seus eleitores. Contudo, ao mesmo tempo, ao legislador se lhe exige que atue racionalmente. A razão deve determinar os conteúdos das normas jurídicas que cria. Se a razão leva ao legislador a verdade, não pareceria que a vontade de seus eleitores seja relevante. Os cidadãos deveriam aceitar os mandatos da razão. A razão deveria privilegiar-se sobre a vontade. Os cidadãos, se sabe, continuamente se deixam levar por emoções e preconceitos que entorpecem o exercício adequado da razão. Claro, na prática as coisas são distintas enquanto que o legislador falha continuamente no uso da razão e privilegia sua própria vontade ou a de seus eleitores. As criações legislativas sempre estão sujeitas a processos de crítica e reforma de maneira que se ajustem aos mandatos da razão.

Não é casual, portanto, que o produto por excelência desta forma de liberalismo seja o código, representado paradigmaticamente pelo Código de Napoleão de 1804. Um produto legislativo que se entende no século XIX francês como englobante, atemporal e universal. O código civil se concebe pela escola da exegese como o conjunto de normas jurídicas que regula todas as matérias relacionadas com as interações que podem dar-se entre as pessoas que compõem uma comunidade política. O código regula a vida das pessoas desde que nasçam até que morram: desde quando se considera juridicamente que um indivíduo tenha nascido, passando pelo matrimonio, pela propriedade, ou pela maneira em que se passar uma sucessão. Pode-se dizer que o código napoleônico não é o código dos franceses senão o código da razão. Daqui que puderam cruzar as fronteiras sem nenhuma dificuldade e fora imposto justificadamente às comunidades militarmente derrotadas pelas campanhas imperiais de Napoleão. O liberalismo francês crê em uma razão universal e atemporal que quando usada apropriadamente gera produtos jurídicos oponíveis a qualquer indivíduo em qualquer período histórico.

Na América Latina, esse discurso normativo, essa forma de conceber o direito e a política, se materializa de maneira paradigmática nos códigos civis de muitos dos países da região e na ideia amplamente aceita de que o verdadeiro direito é o direito civil. Não é uma coincidência que ainda hoje em nossas faculdades se diga que "quem sabe direito civil, [portanto, quem conhece o código civil] sabe direito". Os códigos civis de muitos Estados 
latino-americanos foram fortemente influenciados pelo Código de Napoleão. Os transplantes jurídicos realizados no século XIX por Andrés Bello no Chile, Vélez Sarsfield na Argentina e Teixeira de Freitas no Brasil seguem vigentes na primeira década do século XXI. A expedição do Código Civil chileno em grande parte como consequência do trabalho de importação do Código Civil francês de 1804 realizado por Bello, assim como sua reprodução em países como Colômbia e Equador, são feitos particularmente poderosos que coletam e projetam os valores políticos e jurídicos defendidos pelo movimento codificador e pela escola da exegese francesa. $\mathrm{O}$ discurso formalista latino-americano identifica o ordenamento jurídico com o direito civil e, a este com um conceito de direito que se estrutura em torno às ideias de sistema, completude, autonomia, coerência, univocidade e legitimidade democrática daqueles que detenham o poder criador do direito.

Por outro lado, o formalismo jurídico latino-americano se liga com o historicismo alemão. Para o historicismo, o direito não é um sistema qualquer. O sistema jurídico é análogo às matemáticas. Um sistema composto por um conjunto de axiomas de qual se derivam um grupo regras claras e precisas. $\mathrm{O}$ formalismo recolhe do historicismo alemão a ideia de que o direito deve ser um sistema fechado, autônomo, e composto por um conjunto de normas jurídicas hierarquizadas e abstratas. Em um nível superior se encontram os princípios e em um inferior as regras, que se deduzem daqueles. Nestes princípios e regras aparecem explícita ou implicitamente uma série de conceitos como liberdade, igualdade, capacidade, propriedade, que constituem o núcleo central do sistema. Embora para o historicismo alemão os princípios se devem induzir das práticas sociais normativas da comunidade, no formalismo latino-americano, influenciado pela escola da exegese, tais princípios são resultado da razão do legislador.

Para o historicismo, assim como para o formalismo, o direito é um sistema dedutivo e silogístico. Daí que para estas duas perspectivas teóricas se pode falar de uma ciência do direito. O direito não é uma disciplina que se diferencie em seus métodos das ciências sociais ou das ciências naturais. O ideal do século XIX da criação de um só método científico que permita conhecer a verdade e que seja o tronco comum de todas as ciências faz parte dos postulados defendidos pelo historicismo alemão e o formalismo latino-americano. Daí, então, que tanto um como outro distanciem o direito da realidade social e queiram converte-lo em um céu de conceitos puros e racionais. Em destaque de valores como a claridade, precisão e coerência, o direito deve depurar-se de qualquer variável que o conecte 
com a contingência e a confusão que são comuns na vida social. O céu dos conceitos, criado por Savigny, é o sonho dos conceitos ao que aspira chegar o formalismo latino-americano.

Não obstante, tanto para o historicismo como para a escola da exegese e do formalismo, estes princípios racionais se vinculam estreitamente com o direito romano. No Corpus Iuris Civilis, supostamente se encontra a estrutura básica do direito civil contemporâneo. Daí que hoje em dia na América Latina a maioria dos programas de direito incluam cursos obrigatórios de direito romano. "Aprender o direito romano é aprender os fundamentos do direito civil", se diz continuamente. Desta forma, em tais cursos o tempo deixa de existir. Os professores e estudantes se situam em um eterno presente em que o direito civil sempre "é". O direito civil, o verdadeiro direito, não tem variado substancialmente através dos séculos. A essência do direito romano/civil não se tem visto afetado pelas mudanças econômicas, políticas e sociais ocorridas desde o século VI, momento em que Justiniano compilou o Corpus Iuris Civilis. Nestes cursos de direito romano o espaço também desaparece. As normas jurídicas romanas se ensinam de maneira completamente descontextualizada. Os únicos referentes históricos que se mencionam são os nomes dos protagonistas dos casos que se discutem, Caio, Tício e Ulpiano, por exemplo. Conhecer o direito é, portanto, conhecer um conjunto abstrato de princípios, regras e conceitos. Os efeitos que estes produzem na realidade social, assim como suas origens políticas ou justificação moral resultam marginais para os juristas, ainda quando podem ser de importância para sociólogos, estudiosos da política e filósofos.

\section{0 conceito de direito formalista, a academia jurídica e a prática profissional}

O formalismo jurídico tem moldado a investigação jurídica e o ensino do direito a sua imagem e semelhança. Para o formalismo, a tarefa fundamental do acadêmico deve ser a sistematização do direito. Os professores devem investir todo seu tempo e energia para precisar os conteúdos das instituições jurídicas e determinar a relação lógica e material que existe entre elas. O acadêmico deve organizar, esclarecer e indicar os limites dos princípios e regras jurídicas de maneira que o sistema efetivamente seja um conjunto de conceitos e mandados hierarquizados, claros e coerentes. Seu labor fundamental é, então, a de fazer dogmática jurídica. Daí que, por excelência, o produto final de sua função seja o tratado: um texto que pretende sistematizar a legislação, principalmente os códigos, e portanto, definir 
seus conteúdo e ordenar suas partes. Nos tratados, a área do direito estudada deve aparecer como completa, coerente e fechada.

Contudo, na América Latina, é excepcional encontrar um tratado que alcance os níveis de excelência da dogmática conceitualista alemã que os origina e justifica. A maioria destes textos são realmente glosas aos códigos; documentos que no lugar onde se reproduz sua estrutura, se repete a lei com outras palavras e se fazem comentários mais ou menos marginais a seus conteúdos. Estes comentários se dirigem a evidenciar e solucionar os problemas com os que pode encontrar-se o advogado praticante. O tratado, tipicamente, não é outra coisa que um código comentado. É muito pouco comum que incluam avaliações críticas sérias da legislação, reflexões sobre a eficácia das instituições jurídicas, ou analisem as consequências que as normas estudadas têm na realidade social. Contudo, são uma fonte poderosa de prestigio dentro da comunidade jurídica. $\mathrm{O}$ tratadista é visto com respeito dentro da profissão. Ele é quem ordena o direito e fixa as interpretações padrões das normas e instituições jurídicas.

O tratado, por conseguinte, teorna-se um instrumento fundamental para a reprodução do formalismo jurídico na região. Todos os advogados latino-americanos, em maior ou menor grau, se educam com este tipo de textos. Os tratados são os materiais de estudo por excelência nas faculdades de direito. Ainda mais, alguns tratados clássicos têm sido centrais para a educação de várias gerações de advogados. Resulta surpreendente que a maior parte dos livros com os que se educam as atuais gerações sejam os mesmos com os que se formaram as mais antigas. Não é raro encontrar em nossas bibliotecas e livrarias tratados editados 20 ou 30 vezes e que os estudantes e professores os considerem a fonte principal e inevitável para o estudo do direito. Desta forma, os alunos usualmente terminam convencidos de que os tratados descrevem fielmente o que o direito é e deve ser. Consequentemente, quando chegam à prática profissional defendem ou põe em ação o conceito de direito formalista que aparece implícito neste tipo de materiais acadêmicos. Nenhum tratado, é preciso fazer notar, defende explicitamente o formalismo; não inclui seções teóricas que explicitem os pressupostos que justificam seu conteúdo, estrutura e metodologia evitando, desta forma, sua crítica. O compromisso com o formalismo aparece no objeto de estudo do tratado - a lei e unicamente a lei -, sua organização - a reprodução do esqueleto do código - e o método através do qual se aborda o objeto de estudo - a sistematização acrítica e descontextualizada dos materiais jurídicos, no melhor dos casos; a glosa, na maioria deles. 
Agora, se o formalismo jurídico tem tido um impacto notável na construção da identidade do acadêmico do direito latino-americano, sua influência na maneira em que se pensam as estruturas curriculares e a docência tem sido ainda maior. Os programas de estudos e da docência nas faculdades de direito latino-americanas são profundamente formalistas.

Em primeira instância, são programas e práticas docentes egocêntricas. A educação jurídica formalista gira em torno do estudo de uma e somente uma das fontes criadoras de direito que pode ter um sistema jurídico: a lei. Fontes alternativas, como a jurisprudência, a doutrina e os princípios gerais de direito são consideradas marginais para a formação das novas gerações de advogados. As normas jurídicas promulgadas pelo legislador, indicam o formalismo, estão - e devem estar - situadas no topo do sistema de fontes criadoras de direito. Hoje em dia ainda é comum que as classes de direito das faculdades latinoamericanas girem em torno da leitura do código por parte do professor e aos comentários que este faz sobre um ou outro artigo lido, comentários que geralmente têm o objetivo de determinar a "natureza" das instituições jurídicas que estes consagram. O professor formalista, como se poder ver, é essencialista. Para esse tipo de acadêmicos, as instituições e conceitos jurídicos têm uma "natureza". O contrato, a propriedade, a responsabilidade civil, por mencionar alguns exemplos, são categorias imutáveis que habitam o mundo das ideias. Umas vez que o estudante é capaz de repetir as características necessárias de uma categoria jurídica, haverá entendido o que esta tem sido, é e será no ordenamento jurídico. O caráter contingente das normas e sua conexão com as relações materiais de poder na sociedade se perdem completamente. O princípio de separação do direito e da política volta a aparecer.

Em segunda instância, estes programas e práticas são enciclopédicos. Os programas das faculdades de Direito latino-americanas usualmente incluem um número muito alto de matérias. Os estudantes, se afirma, devem conhecer minuciosamente todas as criações do legislador, devem dominar todas as normas jurídicas que se coletam nos códigos. É comum ver que os estudantes das faculdades de direito latino-americanas tenham que cursar entre seis e dez matérias por semestre. Claro, cursar esse número de aulas somente é possível se o rol de estudantes é indiferente a receber passivamente a informação repassada pelo professor. O tempo que o estudante deve investir para assistir a esses cursos, entre 18 e 30 horas de aulas semanais, exige que assim seja. $\mathrm{O}$ espaço para a pesquisa, assim como para a 
apropriação por parte do estudante das ideias que se discutem nas aulas resulta, na prática, inexistente.

Em terceira instância, a educação jurídica formalista promove a separação entre dogmática, teoria do direito e formação prática, assim como a primazia da primeira sobre as outras duas. $\mathrm{O}$ núcleo das estruturas curriculares devem ser as aulas de dogmática jurídica. Estas são aulas em que os professores e estudantes se acercam ao direito através dos códigos e tratados onde, se supõe, se tenha sistematizado a área do direito que está em estudo. As aulas de filosofia do direito, teoria do direito, teorias da justiça ou as aulas práticas não se incluem nas malhas curriculares ou são marginais. Portanto, isto implica que os professores de teoria, ou de prática, ocupem uma posição política baixa dentro da hierarquia informal que se dá em todas as estruturas universitárias. Isto implica, por exemplo, que a distribuição dos recursos não favoreça a estas matérias e professores, por exemplo, com a contratação por tempo indeterminado ou o financiamento de suas pesquisas.

Esta dissociação também tem como consequência a separação entre teoria e prática. Uma coisa é a dogmática, que supostamente dará ao jovem advogado as ferramentas para atuar na prática profissional, e outra coisa, o discurso filosófico em torno do direito que o formalismo considera bem mais útil. Não obstante, para o formalista dimanam ainda mais inúteis às experiências práticas que ocasionalmente têm os estudantes nas faculdades de direito. Na medida em que a teoria do direito e a prática jurídica a lei não é o único e fundamental objeto de estudo, o formalista as considera como matérias dispensáveis ou secundárias.

Agora, torna-se estranho que este tema usualmente se apresente como um debate sobre a relação que deve haver entre teoria e prática. A dogmática jurídica que favorecem os professores formalistas é teoria, não prática. A diferença está só no nível de abstração que esta e a filosofia do direito têm. Enquanto que a dogmática tem um nível médio de abstração, sempre ancorada à lei, a teoria do direito tende à alcançar níveis altos de abstração haja vista que se preocupa com problemas com um maior grau de generalidade. De igual modo, se o professor formalista está convencido de que as faculdades de direito devem investir todos seus esforços em formar unicamente praticantes do direito, deveria estar comprometido com os cursos práticos que permitem que os estudantes desenvolvam atividades centrais para atuar competentemente na profissão. Desta forma, o debate não se dá realmente entre professores 
"teóricos" e professores "práticos", senão entre professores com distintos conceitos de direito e, consequentemente, com ideias distintas do que deve ser a educação jurídica.

Em quarta instância, a educação jurídica formalista está comprometida com a separação entre direito privado e direito público, assim como entre as subáreas existentes em cada um destes campos, entre outros, direito penal, trabalhista, civil e comercial. O núcleo de qualquer malha curricular, afirma o formalismo latino-americano, deve ser o direito privado. A tradição civilista à que pertence o direito dos países da região se ocupa principalmente das relações entre os cidadãos, não das relações entre o Estado e o indivíduo. Como se disse anteriormente, no direito romano se encontram as bases do direito privado latino-americano. O direito regula as relações entre as pessoas; a política, as interações entre o Estado e os sujeitos. O direito público se apresenta no formalismo como um campo onde a separação entre o estritamente jurídico e o político desaparece.

Não há que esquecer que, como uma ferramenta do liberalismo francês do século XIX, na América Latina ainda muitos advogados consideram que as Constituições são textos meramente para aspiração, sem nenhum valor normativo. Daí, por exemplo, que na Colômbia - antes da expedição da Constituição de 1991, a carta de direitos tivera que ser incluída dentro do código civil para que pudesse ser aplicada pelos funcionários públicos e exigida pelos cidadãos. Daí também, porque na Colômbia e México houve tanta resistência na comunidade jurídica para aceitar o que se tem chamado de constitucionalização do direito privado. Um processo em que as fronteiras entre o direito privado e público se tornam porosas e em que o primeiro é interpretado à luz do segundo, particularmente da Constituição, que se entende agora como norma suprema do ordenamento jurídico e de aplicação direta e imediata. Os formalistas argumentam que este processo interação entre as duas principais áreas do direito tem desnaturalizado o direito privado. Cada um destes campos jurídicos responde a lógicas distintas que assim devem manter-se separadas. O formalismo adiciona que esta separação deve dar-se entre as áreas mais precisas que compõem ao direito privado e o direito público. Consequentemente, é uma exceção que na classe de direito comercial se evidenciam as intersecções e interações que este tem com o direito civil e muito menos com o direito penal e o constitucional.

Em quinta instância, a educação jurídica formalista é de memorização. Os alunos devem ter a capacidade de reter e repetir os conteúdos de tantas leis como seja possível. A 
excelência acadêmica está diretamente relacionada com a possibilidade de dar conta de cada uma das palavras que formam as regras criadas pelo legislador. A capacidade de recordar com precisão os conteúdos da lei resulta fundamental para ter êxito na faculdade de direito. Esta característica da educação na América Latina se faz evidente de maneira particularmente forte nas avaliações. Os exames orais ou escritos em que se pergunta pela definição de um conceito jurídico ou a enumeração dos requisitos necessários para que um contrato determinado se considere válido, são hoje em dia comuns nas universidades latino-americanas.

Em sexta instância, a educação formalista é uma educação descontextualizada. O direito pode, e deve, estudar-se sem aludir à sociedade onde se promulga e aplica. O estudante deve conhecer unicamente as leis que estruturam o ordenamento jurídico - o qual, como se disse acima, é considerado como um sistema fechado e completo. O estudante deve mover-se com fluidez nos caminhos que levam dos princípios às regras e das regras aos princípios. $\mathrm{O}$ que sucede nas áreas da sociedade que colidam com os limites claros e precisos do ordenamento jurídico não tem nenhuma importância para os operadores jurídicos.

Em sétima instância, o formalismo oferece aos estudantes uma educação acrítica. As perguntas pela legitimidade e eficácia das normas jurídicas resultam irrelevantes. Os temas relacionados com a justificação moral do direito e suas consequências, argumenta-se, são objetos de estudo apropriados para os departamentos de filosofia e sociologia, não para as faculdades de direito. É comum que os professores escapem ou desqualifiquem as perguntas dos estudantes sobre a justificação moral ou política de alguma norma, ou as consequências efetivas que esta gera na sociedade. Estas perguntas, se diz, deveriam fazer-se aos estudiosos da política e filósofos políticos. "Nesta aula", se conclui em muitas das aulas formalistas, "se vem a estudar direito, não humanidades ou ciências sociais".

Em oitavo lugar, a educação jurídica formalista considera a aula magistral como único método de ensino. Este método, tal e como é interpretado pelo formalismo, parte de duas premissas. Por um lado, existe uma relação vertical entre professor e aluno. $\mathrm{O}$ primeiro domina e transmite um conhecimento especializado; o segundo o desconhece e recebe passivamente. Por outro lado, na interação entre professores e alunos não se cria conhecimento. O saber não tem a possibilidade de construir-se coletivamente nas salas de aula, este preexiste ao encontro material que se dá entre instrutores e estudantes. Isto não quer dizer que a aula magistral seja necessariamente um método de ensino formalista. Este tipo de 
aula pode cumprir fins valiosos dentro de uma faculdade de direito quando se usa em conjunto com outros métodos pedagógicos. Pode, por exemplo, ser o espaço onde professores experientes apresentam o marco teórico que permitirá aproximar-se a um problema jurídico particular, marco e problema que logo serão postos em questão em seminários guiados por professores que iniciam sua carreira acadêmica.

Finalmente, em nona instância, o formalismo tem determinado que a docência e a investigação jurídica sejam desenvolvidas por professores hora-aula. A profissionalização da academia jurídica é um fenômeno recente e incipiente na maior parte das faculdades de direito latino-americanas. O corpo docente, historicamente, tem estado constituído por advogados praticantes e juízes. As aulas são realizadas e os tratados escritos fora da jornada de trabalho bem cedo pela manhã ou tarde da noite. $\mathrm{Na}$ medida em que a faculdade de direito está direcionada fundamentalmente à formação de profissionais que conheçam as criações do legislador e os desafios práticos básicos que a vida laboral do advogado impõe, não se considera uma necessidade a contratação de professores em dedicação exclusiva à docência e à pesquisa jurídica. Os litigantes/assessores e juízes são quem detém o saber necessário para educar as novas gerações de advogados. A prática privada e a vida no judiciário mantêm e atualizam constantemente esse saber. Sem a menor dúvida, alguns destes professores estão comprometidos com a docência e a criação de conhecimento jurídico. Contudo, as restrições impostas pelos trabalhos exigentes de advogados praticantes e juízes, não lhes permitem dedicar maior tempo à academia.

Agora, a hegemonia da educação jurídica formalista também tem condicionado aspectos centrais da prática profissional latino-americana. No âmbito judicial, o formalismo tem logrado que a interpretação mecanicista da decisão judicial se converta na referência central para descrever e avaliar o trabalho dos juízes latino-americanos. De fato, esta interpretação tem sido interiorizada por boa parte do judiciário. Argumentos como a neutralidade do juiz, a interpretação exegética e a supremacia da lei no sistema de fontes são comuns no discurso que os próprios juízes usam para descrever e avaliar a atividade que desenvolvem como autoridades públicas. De igual forma, o formalismo tem relegado o mercado de trabalho dos advogados à prática profissional privada ou à burocracia estatal. A maior parte dos jovens advogados nem sequer contempla a possibilidade de trabalhar em organizações não governamentais, escritórios de advogados dedicados ao direito de interesse público ou à academia. Este tipo de trabalhos não se ajusta à imagem de advogados com a 
qual estão comprometidos implícita ou explicitamente. Não combina com a identidade de advogado ideal que tem se construído da mão do formalismo. O "verdadeiro advogado", afirma-se, se dedica ao litígio, à consultoria privada, ou a ocupar os quadros médios da burocracia estatal.

A primazia do mecanicismo judicial para descrever o que os juízes fazem ou devem fazer e a restrição injustificada do mercado laboral do advogado, são algumas das consequências que o formalismo jurídico tem gerado para a prática profissional. Contudo, para os fins que persegue este texto, têm outros três efeitos que resultam de maior importância. O primeiro é a formação de advogados que tendem a não reconhecer suas obrigações morais com respeito à comunidade política. O único dever que devem atender, se diz continuamente, é o de representar de maneira competente e ética os interesses de seus clientes. Desta forma, os advogados formalistas perdem de vista as responsabilidades sociais que gera o fato de deter um saber especializado a que poucos indivíduos têm acesso e que possui importantes efeitos na construção da esfera pública dos países da região.

Resulta particularmente revelador e ilustrativo, por exemplo, que as palavras "trabalho pro bono" não tenham sentido para a maior parte dos advogados latino-americanos. Este conceito só recentemente tem começado a permear alguns poucos setores das comunidades jurídicas latino-americanas, particularmente o das grandes firmas de advogados. O compromisso como o trabalho jurídico não remunerado que se faz "pelo bem da comunidade" que se evidencia na redação e assinatura da Declaração Pro Bono das Américas, assim como na criação e consolidação de fundações que promovem este tipo de trabalho no Chile, Argentina e Colômbia são a exceção, antes que a regra. A posição da maioria dos advogados latino-americanos se mostra bem mais no fato de que alguns grandes escritórios da região tenham decidido não assinar esta declaração, na medida em que lhes parecia excessiva a única obrigação efetiva que gera a seus subscritores: cada advogado dedicar 20 horas por ano ao trabalho pro bono. É dizer, a estas empresas lhes parece excessivo dedicar menos de um dia por ano a algum tipo de trabalho jurídico não remunerado que contribua à garantia de valores como o acesso à justiça, ao devido processo ou a justiça material.

O segundo efeito, diretamente relacionado com o anterior, é a separação radical entre comunidade jurídica e sociedade. Os advogados, como coletivo, usualmente se preocupam muito pouco pelos problemas e necessidades da comunidade política. 
Comumente, as associações, colégios ou firmas de advogados não se perguntam pelos caminhos através dos quais o sistema jurídico e os profissionais do direito podem contribuir a solucionar os conflitos sociais ou materializar os projetos políticos normativos comuns, por exemplo, a consolidação do Estado de Direito. Os coletivos que reúnem os advogados, a maior parte das vezes, são associações que buscam o lucro de seus membros ou a defesa de interesses internos. Esta separação entre comunidade jurídica e realidade faz que o direito muitas vezes deixe de considerar-se um meio para alcançar objetivos valiosos na comunidade política e passe a converter-se em um fim em se mesmo, ou em um meio para garantir o benefício patrimonial daqueles que conhecem seu discurso especializado.

O terceiro efeito, tem a ver com as dificuldades que têm os advogados jovens para aplicar a informação que aprenderam na faculdade. Uma vez que se graduam, os advogados se encontram com grandes dificuldades para atuar na prática profissional embora conheçam com maior ou menor precisão as normas jurídicas aplicáveis às atividades ou conflitos que enfrentam. Os jovens advogados evidenciam rapidamente, através do choque direto com a realidade prática, que não têm desenvolvido ou consolidado destrezas fundamentais para atuar competentemente na profissão. Carecem de habilidades para a argumentação jurídica escrita ou oral, não sabem entrevistar um cliente para precisar os efeitos juridicamente relevantes do caso, não sabem trabalhar em equipe com colegas ou profissionais de outras disciplinas, ou redigir um contrato comum na prática privada.

Enquanto que a educação jurídica formalista gira em torno da informação, as matérias que permitam o desenvolvimento de destrezas não existentes dentro do currículo ou estão nas margens do mesmo. Isto não quer dizer que as faculdades de direito deveriam ter como objetivo a formação de advogados "técnicos" destinados a trabalhar nos escritórios de advogados ou nos níveis médios do Estado. Quero dizer que as faculdades de direito devem garantir que seus graduandos, logo após passar cinco anos da universidade, desenvolvam as habilidades próprias da disciplina em níveis aceitáveis. Estas destrezas permitiram que os jovens advogados possam atuar com competência nos diversos nichos que o mercado laboral lhes abre, desde as organizações internacionais até as organizações não governamentais de base, passando pelo Estado e as empresas de litigantes ou consultores. A afinação destas habilidades ou aquisição de algumas mais especializadas, certamente, devem desejar-se lhe ao novo ciclo de aprendizagem que se inicia quando se entra no mercado de trabalho. 


\section{Os núcleos de prática jurídica de interesse público e o formalismo jurídico}

Os núcleos de prática jurídica de interesse público são um dos espaços onde se tem desenvolvido a luta contra o formalismo jurídico, a academia e a prática que este conceito de direito tem gerado na América Latina. Os três principais objetivos que geralmente buscam os núcleos de prática jurídica de interesse público põem em questão os eixos que estruturam o formalismo. Por um lado, o direito se concebe como um instrumento de mudança social. $\mathrm{O}$ direito é interpretado e utilizado como uma ferramenta para a criação de uma sociedade mais justa, embora as distintas experiências de núcleos latino-americanos assumam interpretações diversas desta ideia ou o que esta exige em um caso particular. Daí que o trabalho dos núcleos latino-americanos se tenham concentrado em projetos de proteção dos direitos das minorias, comunidades indígenas e homossexuais, por exemplo, a proteção de bens jurídicos coletivos, como o ambiente e a saúde pública, ou a defesa de princípios constitucionais básicos, como o acesso de todos os cidadãos à justiça.

Por outro lado, os núcleos de prática jurídica de interesse público estão comprometidos com o ensino empírico. Este tipo de projeto considera que os currículos devem incluir matérias que permitam aos estudantes "aprender fazendo". Os alunos devem desenvolver atividades típicas da prática jurídica, de maneira que possam desenvolver habilidades e interiorizar informações pertinentes para a vida profissional. Essas atividades devem avançar sob a constante orientação e supervisão de um professor. O diálogo contínuo com o docente, assim como com seus companheiros, revela-se fundamental para que o estudante possa avaliar e aprender de suas ações. A retroalimentação e a crítica permanente de seus pares e professores são fundamentais para que o estudante possa tomar distancia de sua própria prática. Só assim poderá evidenciar suas forças e debilidades, assim como a maneira em que deverá atuar em novos processos de aprendizagem dentro e fora da faculdade para que as primeiras se consolidem e as segundas se neutralizem.

Finalmente, os núcleos de prática jurídica de interesse público consideram que o ensino do direito deve ter como um de seus objetivos centrais a aquisição de habilidades que a disciplina considera como próprias. Não se argumenta que se deva deixar de lado o ensino de conteúdos. Contudo, se enfatiza que os estudantes devem poder aplicar essa informação à realidade social. Para alcançar este objetivo necessitam desenvolver habilidades como a 
argumentação oral e a articulação de problemas jurídicos, desenvolver habilidades críticas para o questionamento das normas jurídicas existentes e adquirir estas destrezas atuando, isto é, enfrentando tarefas como as que tipicamente realiza um advogado na prática profissional.

Os núcleos de prática jurídica de interesse público podem ser divididos em dois grandes grupos. Por uma parte, aqueles que têm como principal objetivo a defesa do direito de acesso à justiça de todos os cidadãos, e que neste texto queria chamar de "Clínicas Acceso a la Justicia $(\mathrm{CAJ})^{2}$. Estes núcleos têm como fim garantir a defesa jurídica de qualidade a pessoas de baixo recurso econômico. O caso típico é a representação de um indivíduo ante uma corte penal, laboral ou civil onde o estudante busca defender os direitos dos que este é titular. Um exemplo deste tipo de núcleo são as que existem em todas as faculdades de direito colombianas há um pouco mais de 30 anos. Por mandato jurídico, todos os estudantes de direito da Colômbia devem participar por um ano no que se chama usualmente de Núcleo Jurídico $^{3}$. Usualmente, qualquer cidadão de baixa renda pode recorrer a eles para pedir assessoria ou solicitar que um estudante de direito o represente ante um tribunal.

Como se pode ver, as CAJ centram seu trabalho na defesa dos direitos de uma pessoa dentro de um processo judicial típico. Como o faz geralmente um advogado privado, os estudantes dos núcleos deixam de lado os problemas que não afetam de maneira direta e imediata a seu representado. Desta forma, não incluem dentro de suas ações, os conflitos sociais gerais que podem ser a causa do problema que enfrenta seu cliente, ou a necessidade de fixar um precedente judicial que possa dar lugar a uma mudança na maneira em que se resolvem os casos semelhantes.

O segundo grupo de núcleos, que queria chamar "Clinicas Cambio Social Estructural" (CCSE), tem como objetivo contribuir para a solução de um problema que afeta algumas das bases da estrutura social. Desta forma as CCSE não só buscam representar competentemente a seu cliente, senão que, com seu conhecimento, aceitação e apoio, intentam que haja uma transformação estrutural na sociedade através da solução de conflito que este indivíduo ou grupo de indivíduos enfrenta.

As três seguintes são as estratégias mais comuns que este tipo de núcleo usa: primeiro, o litígio de alto impacto. Mediante esta estratégia, as CCSE buscam uma transformação macro social através da apresentação de um caso (ou conjunto de casos) ante a 
administração da justiça. De ter êxito, se afetará positivamente a todos os indivíduos que enfrentam o problema, em torno do qual gira a demanda. A apresentação de uma demanda de inconstitucionalidade que busca declarar inválida uma lei que viola o direito à igualdade das mulheres, resulta um bom exemplo deste tipo de estratégia. Segundo, a assessoria legislativa. Mediante este tipo de ferramenta, as CCSE buscam que os Congressos aprovem leis consideradas de interesse público, contribuir para a avaliação pública dos projetos de lei que cursam nas legislaturas, desenvolver atividade de lobby junto aos congressistas, de modo que apoiem ou questionem propostas legislativas particulares, e redigir projetos de lei que possam ser apresentados diretamente ou por organizações sociais ou políticas que dividem seus conteúdos. Terceiro, desenvolver trabalhos de pedagogia jurídica que permitam que os cidadãos, particularmente os que pertencem a grupos vulneráveis ou historicamente discriminados, conheçam seus direitos e os meios jurídicos que existem para defendê-los. Projetos de educação nas prisões é um exemplo ilustrativo deste tipo de estratégia. Nestes projetos se busca que os internos conheçam seus direitos e os meios jurídicos para enfrentar as ações dos funcionários das penitenciárias que violam estes direitos.

Como se pode ver, as CAJ e as CCSE são complementares. Enquanto que estas últimas enfrentam - acudindo a uma metáfora geológica - problemas tectônicos, aquelas enfrentam problemas de superfície. Desta forma, os assuntos que manejam os dois tipos de núcleos estão inter-relacionados estreitamente. Os problemas nas placas, que constituem a estrutura da comunidade política, são a causa de boa parte dos problemas da superfície social. Enquanto que as CAJ se centram nos direitos dos indivíduos que representam, as segundas se concentram nas tensões estruturais que geram os conflitos que seus clientes e outros indivíduos em situações análogas enfrentam. Os dois tipos de tarefa têm enorme importância.

Assim, por exemplo, para o cliente que chega a um núcleo jurídico colombiano, faz-se fundamental que o estudante que o representa interponha em seu nome uma ação de tutela que lhe permita ter acesso a um medicamento ou um procedimento médico que uma empresa prestadora de serviços de saúde lhe tenha negado. Os direitos que interessam a este indivíduo são, com toda razão, seu direito à saúde e à vida. O problema geral do sistema de seguridade social, que leva um número muito alto de cidadãos a não terem acesso aos serviços necessários para enfrentar eficientemente os problemas de saúde que os afligem, não se torna central para este cidadão ou para o estudante que o representa. Contudo, sim, é de principal interesse para as CCSE. Seu objetivo é lograr que através de um caso particular, se possa 
gerar uma reforma geral do sistema de seguridade social que obrigue as empresas prestadoras de serviços de saúde a satisfazer as necessidades justas de seus afiliados. Este objetivo pode implicar, por exemplo, articular uma estratégia de litígio que obrigue a Corte Constitucional a pronunciar-se sobre o tema estrutural, ou redigir um projeto de resolução que, após o lobby necessário, permita que o Ministério da Saúde mude os medicamentos ou procedimentos médicos incluídos nos planos obrigatórios de saúde.

Os dois tipos de núcleos trabalham em frentes distintas, mas com um fim comum: a consolidação do Estado de Direito nos países da região. Embora cada um desses núcleos latino-americanos defendam interpretações distintas do que este exige, todas buscam que a comunidade política materialize as disposições que se reúnem nas cartas políticas que regem em seus países. As CAJ enfrentam, principalmente, um dos problemas mais sérios que têm as democracias latino-americanas: a impossibilidade que possui a maioria dos cidadãos de acessar a administração da justiça ou obter serviços jurídicos de qualidade. Os serviços que prestam estes núcleos são urgentes e de imensa importância para os cidadãos: geralmente, enfrentam conflitos que poderiam afetar notavelmente a liberdade ou o patrimônio das pessoas mais pobres da sociedade. De igual forma, este tipo de núcleo permite que os estudantes se aproximem da realidade social dos países em que residem, tenham consciência de seus deveres profissionais e desenvolvam as habilidades necessárias para atuar competentemente na prática profissional.

As CCSE enfrentam distintos tipos de problemas tectônicos que afetam as comunidades políticas da região. O que resulta fundamental para este tipo de núcleo não é o tema particular, senão o impacto que tem sobre populações vulneráveis e seu caráter estrutural. Este tipo de núcleos assumem casos que vão desde a violação sistemática dos direitos culturais das comunidades indígenas, até o desconhecimento histórico de direito à igualdade de minorias sexuais, passando pela violação continua dos direitos sexuais e reprodutivos das mulheres latino-americanas. De igual forma, assumem casos que encaram o racismo estrutural que existe em muitos de nossos países, a discriminação pública e privada dos cidadãos de escassos recursos econômicos, uma característica de países da região com níveis de desigualdade históricos notáveis, e o esforço contínuo de muitos governos latinoamericanos por controlar a informação disponível na sociedade. 
Agora, embora o trabalho das CAJ e CCSE seja complementário, sua instituição se tem dado em momentos distintos. Na América Latina, as CAJ emergem e se institucionalizam antes que as CCSE, como consequência das ações que avançam o movimento sobre direito e desenvolvimento em prol da educação jurídica "clínica" e seu financiamento por parte do United States Agency for Internacional Development e a Fundação Ford nos anos sessenta e setenta. Os núcleos (“clínicas”) que existem em todas as universidades colombianas e chilenas são um bom exemplo deste tipo de projeto. Em contraste, as CCSE são muito mais recentes. Os primeiros núcleos deste tipo surgem por volta da década de 90 como consequência dos esforços de alguns professores de direito comprometidos com a justiça social. Os núcleos prática jurídica de direito de interesse público das universidades de Palermo e Diego Portales são boas ilustrações desta primeira geração de CCSE na região. Não obstante, a maior parte das CCSE latino-americanas surgem nos últimos cinco a sete anos; por exemplo, o núcleo da Fundação Getúlio Vargas em São Paulo (Brasil), o núcleo da Universidade de Rosário (Argentina), o novo núcleo do Instituto Tecnológico Autônomo do México, e Justiça Global, o Grupo de Direito de Interesse Público e o Programa pela Inclusão Social da Universidade dos Andes (Colômbia).

Apesar de que buscam objetivos específicos distintos e que surgem em contextos diferentes, ambos os tipos de núcleos têm como eixo comum o questionamento do formalismo jurídico. Estes projetos, portanto, têm enfrentado sérios obstáculos externos e internos que têm dificultado sua criação ou desenvolvimento. A teoria e a prática "clínica" chocam com o conceito de direito dominante e, consequentemente, com todos aqueles operadores jurídicos que o defendem explícita ou implicitamente.

O primeiro obstáculo constitui a oposição política das diretivas, assim como de alguns núcleos de professores - tanto nas faculdades de direito como em outras faculdades e na administração central das universidades. Três razões explicam esta oposição: por um lado, os núcleos ("clinicas") são vistas com suspeita enquanto que geralmente se lhes associa automaticamente com visões político-jurídicas de esquerda, em virtude de seu compromisso com a defesa dos direitos de grupos historicamente discriminados ou vulneráveis da sociedade. Por outro lado, os vê como um risco para a hegemonia do formalismo jurídico. Os professores conservadores veem com preocupação como os valores com os que estão comprometidos - a lei como centro de tudo e o enciclopedismo, por exemplo - são questionados pelo trabalho e pela teoria dos núcleos. Finalmente, esta oposição aparece pelo 
que poderíamos chamar de "conservadorismo institucional" de alguns diretores ou professores universitários. A oposição destas pessoas não se deve ao conteúdo das causas que desenvolvem os núcleos senão, bem mais, as consequências que estes projetos podem ter para a imagem pública, a governabilidade ou a estabilidade institucional da universidade.

Nas universidades privadas, este temor aparece quando o trabalho dos núcleos toca em temas que afetam negativamente os membros da própria comunidade. Por exemplo, integrantes das juntas da diretoria, ex-alunos, ou grupos de pesquisa que dependem de financiamento governamental ou privado. Nestes casos, a direção se opõe ao trabalho do núcleo devido às tensões que prova em grupos de interesse que compõem a universidade, ou com os que esta interatua constantemente. Nas universidades públicas, a suspeita frente os núcleos aparece como consequência dos problemas políticos externos que seus projetos podem gerar. Os partidos políticos ou organizações não governamentais, por exemplo, podem questionar a universidade por impulsionar iniciativas com altos conteúdos políticos que geram divisões entre a cidadania. Este tipo de projeto, argumenta-se, não deve ser desenvolvido por uma universidade pública, que supostamente não deve se comprometer com uma orientação política particular. Estes questionamentos, podem gerar problemas nos conselhos diretivos das universidades onde há presença do governo ou obscurecer decisões dos ministérios ou o congresso sobre como tem que se distribuir o investimento financeiro entre as universidade públicas.

Usualmente, estas preocupações não se articulam em torno dos compromissos políticos ou dos conceitos de direito que cada grupo de professores ou diretores defende. Mas, o debate aparece de maneira implícita em controvérsias sobre como devem distribuir-se os recursos escassos na universidade, a imagem que a universidade deve projetar na esfera pública e as características que deve ter a malha curricular do programa de direito. Não obstante, tal oposição gera importantes e bastante negativas consequências para os núcleos. Entre outras coisas, evita que recebam os recursos adequados para funcionar apropriadamente, dificulta que seus professores digam e façam aquilo que consideram necessário para cumprir sua missão e impede que os valores com os quais estão comprometidos permeiem as estruturas acadêmicas das faculdades de direito, por exemplo, que o ensino experimental faça parte importante das práticas pedagógicas da faculdade e se dê importância às dimensões éticas que deve ter a prática profissional. 
Em segundo lugar, o número de professores do núcleo de dedicação exclusiva é muito baixo e não existe vontade política para contratar novos professores que se dediquem a este tipo de projetos ou incentivos para que os professores de dedicação exclusiva, que assim o queiram, possam dedicar parte de suas atividades acadêmicas ao núcleo. Este problema tem direta relação com o feito de que a profissionalização da academia jurídica seja um processo que apenas começa a consolidar-se na América Latina. O número de professores de dedicação exclusiva segue sendo muito baixo na maior parte das faculdades de direito da região. É possível dizer que as dificuldades que enfrentam os projetos dos núcleos são inclusive maiores dos que enfrentam outras áreas da faculdade, enquanto o formalismo jurídico dominante os considera marginais para a educação das novas gerações de advogados.

Em terceiro lugar, os núcleos latino-americanos encontram notáveis contratempos para cumprir seus objetivos devido à escassez de recursos econômicos que existe em muitas faculdades de direito latino-americanas. O problema, neste caso, não é a falta de vontade política para usar parte dos recursos disponíveis nos núcleos, senão que o "bolo" a repartir não é suficientemente grande. Assim, embora os núcleos recebam uma porção mais ou menos justa dos recursos que controla a faculdade, estes não são suficientes para cobrir apropriadamente os gastos necessários para funcionar corretamente, por exemplo, contratando o número adequado de professores de dedicação exclusiva, assistentes docentes e pessoal administrativo, ou melhorando a infraestrutura necessária para acolher tanto os estudantes como as equipes de trabalho. Agora, se os gastos básicos dos núcleos muitas vezes não se podem cobrir com os recursos disponíveis, muito menos o são outro tipo de atividades importantes para o trabalho do núcleo, como a participação de seus professores e estudantes em seminários internacionais, a organização de conferências relacionadas com os casos que estejam desenvolvendo ou a publicação de seus resultados.

Em quarto lugar, a excessiva rigidez dos programas e do sistema político das universidades torna lento, ou impossibilita, a criação de consultório jurídicos de interesse público. Os processos que permitem a variação das malhas curriculares são muitas vezes longos e difíceis, o que desestimula a mudança e promove o status quo curricular. O tempo, energia e capital político que deve ser investido para iniciá-los e levá-los a um bom fim, evita que os professores interessados sequer tentem propor a necessidade de criar um projeto de núcleo em suas faculdades. 
Em quinto lugar aparece o desinteresse de um importante número de estudantes. Depois de vários anos na faculdade, a maior parte deles já tem interiorizado o conceito de direito formalista dominante ou se veem fortemente influenciados pela identificação que se faz entre êxito econômico e êxito profissional nas comunidades jurídicas da região. Consequentemente, não encontram maior valor no trabalho realizado no núcleo. Este não satisfaz as exigências do mercado laboral. Não gira em torno da memorização das leis e não se faz eficiente para posicionar-se na prática privada ou na burocracia estatal. Desta forma, os estudantes preferem ocupar seu tempo em atividades que tornem mais provável a realização deste objetivo, privilegiando, por exemplo, práticas empresariais que as mesmas universidades oferecem ou trabalhos de meio período em escritórios de advocacia.

Em sexto lugar, o trabalho dos núcleos também se vê no obscurantismo, pela falta de clareza em seus objetivos, ou por disputas internas acerca de quais devem ser os fins que estas devem alcançar. É comum que os professores dos núcleos latino-americanos tenham claro o adversário teórico que enfrentam em seu trabalho. Os professores do núcleo da região, implícita ou explicitamente e com diferenças no grau de precisão com o eu articulam o argumento, reconhecem no formalismo jurídico o conceito de direito que se questiona e se transforma com o trabalho do núcleo. Contudo, também é comum que nos núcleos latinoamericanos não se articule (ou não se articule claramente) uma proposta jurídico-política alternativa. Isso não significa que o trabalho do núcleo se desenvolva sem orientação teórica. Não há prática sem teoria - assim, esta só está implícita nas práticas. Não obstante, geralmente, os conceitos de direito que justificam o trabalho que se desenvolve nos núcleos não se fazem explícitos, nem se avaliam. Os professores do núcleo não se detêm em refletir sobre a teoria que os está guiando.

Do mesmo modo, não há clareza, ou consenso, sobre o que se entende por direito de interesse público e justiça, conceitos que os núcleos tentam materializar através de suas ações. O ponto não é que todos os núcleos latino-americanos devam defender uma única interpretação destas ideias. Como é obvio, existem diversas interpretações de interesse público e múltiplos conceitos razoáveis de justiça. Tampouco se trata de que um núcleo deva defender para sempre a mesma interpretação destas duas categorias. Esta interpretação pode variar devido tanto à rotação das pessoas que trabalham no núcleo, como às mudanças nas dinâmicas contextuais e ideológicas que as afetam. Muito menos significa que os professores do núcleo devam ocupar uma boa parte de seu tempo em dissertações sobre filosofia política 
ou teoria do direito. A maior parte deles não são teóricos da justiça ou filósofos do direito e não há boas razões para exigir que assim seja. O argumento é simplesmente que a claridade em torno de como se devem interpretar os conceitos de interesse público e justiça social em cada núcleo resulta fundamental para esclarecer os valores e objetivos que guiam o trabalho, desde a escolha dos casos até os meios que se consideram legítimos para alcançar seus fins.

Em sétimo lugar, a falta de literatura - ou a baixa qualidade de muitas das que existem - que contextualize, apresente, analise e critique os objetivos dos núcleos de prática jurídica de interesse público, os meios para alcançá-los e os processos que na prática se desenvolvem para uns e para outros. Muitos dos núcleos de interesse público da região têm tido um impacto importante em temas chaves para a consolidação da democracia e o respeito dos direitos básicos dos cidadãos. Contudo, a reflexão em torno destas práticas não é frequente e/ou sua qualidade varia notavelmente. É preocupante que na América Latina não exista nenhuma revista sobre educação jurídica realizada nos núcleos e só algumas revistas de direito incluam artigos sobre educação jurídica ou educação jurídica prática. Sem dúvida, a ampla literatura existente nos Estados Unidos é útil para pensar nas distintas facetas que compõem o trabalho clínico latino-americano, desde como alcançar balanços apropriados entre os objetivos pedagógicos e os de justiça social, até os critérios que se devem usar para escolher os casos, passando pelos métodos através dos quais se deve avaliar e supervisionar os estudantes. Não obstante, pareceria exigível que as particularidades do trabalho realizado nos núcleos e o contexto na América Latina fossem um objeto de estudo constante dos professores de direito da região. Temas como a história do que poderíamos chamar de movimento "clínico" latino-americano - os processos de criação, consolidação ou expansão dos núcleos de prática da região -, o rol das fundações e da cooperação internacional na criação destas, o fato de que o trabalho do núcleo se desenvolva em democracias em processo de consolidação, as diferenças entre os projetos "clínicos" que se desenvolvem nas universidades privadas e públicas e a escassez crônica de recursos, entre muitos outros, pareceres que deveriam ser examinados criteriosamente pelos professores de direito latinoamericanos.

Em oitavo lugar, o isolamento ou o contato irregular entre as pessoas que trabalham nos núcleos de prática latino-americanas. Dado que o dinheiro disponível nos núcleos da região não é muito alto, é pouco comum que haja espaço de encontro permanente para os que trabalham nestes temas, seminários ou debates, por exemplo. A ausência destes 
espaços gera consequências negativas, na medida que se torna difícil aprender com experiências que outros têm tido na criação ou desenvolvimento de projetos análogos, e concretizar propostas que permitam unir esforços para a satisfação dos objetivos comuns que tem os núcleos de prática da região.

\section{Núcleos de prática jurídica de interesse público na América Latina: estratégias para sua consolidação}

Os obstáculos que enfrentam os núcleos de prática jurídica de interesse público da região não são poucos e alguns deles são enormemente poderosos. Contudo, os professores e estudantes dos núcleos estão constantemente articulando e implementando medidas para sua superação. As seguintes são algumas estratégias gerais que poderiam ser úteis para enfrentar e neutralizar os problemas observados na seção anterior. Tais estratégias tentam ser o suficientemente precisas para que possam ser um guia efetivo, mas também o suficientemente amplas para serem adaptadas aos distintos contextos nacionais e institucionais da região.

Em primeira instância, é necessário que se organizem e se implementem atividades acadêmicas - seminários, debates, publicações, entre outras ações - que permitam discutir as debilidades da visão formalista do direito e mostrem os benefícios pedagógicos do trabalho que se faz nos núcleos de prática jurídica de interesse público. Este tipo de atividades contribuiria para criar uma massa crítica composta por professores e alunos que pressionem pela criação ou consolidação destes projetos nas universidades. Estas atividades permitiriam definir o adversário teórico assim como os meios adequados para fazê-lo. O formalismo reina na região não porque haja uma defesa clara, precisa e persuasiva de seus postulados nas universidades, tribunais ou colégios de advogados, senão porque se reproduz silenciosamente - quase inconscientemente - nas novas gerações de advogados e nas práticas profissionais cotidianas. Ao fazer explícitos seus postulados, assim como suas debilidades, é possível que seu questionamento resulte mais amplo e efetivo.

Em segunda instância, é necessário articular estratégias e atividades políticas dentro das universidades que permitam evidenciar e ultrapassar os obstáculos que impedem a criação ou consolidação dos núcleos de prática jurídica de interesse público. Desta forma, seria útil, por exemplo, que os professores se manifestem de maneira regular nos conselhos de faculdade à favor dos núcleos, que se questionem as decisões administrativas que afetam seu 
desenvolvimento e se gerem alianças com colegas de outras disciplinas interessados no trabalho destas iniciativas. Estas medidas facilitaram a criação de grupos de pressão sólidos dentro das faculdades e das universidades.

Em terceira instância, a obtenção de recursos financeiros em organizações internacionais ou nacionais que estejam interessados em promover os núcleos de prática jurídica de interesse público na América Latina. Embora resulta fundamental para a consolidação e expansão dos núcleos que seus gastos básicos sejam cobertos pelas universidades, poderia ser útil recorrer a fontes externas de financiamento para o desenvolvimento de novos projetos ou para cobrir aqueles que - embora necessários para o bom funcionamento dos núcleos -, não são custeados pelas instituições que os abrigam. A autonomia econômica que se alcançaria com estes recursos externos permitiriam alcançar maior independência aos que trabalham nos núcleos, garantindo a continuidade de alguns de seus esforços e contribuindo para seu reconhecimento e posicionamento político.

Em quarta instância, fomentar entre os estudantes os núcleos de prática jurídica de interesse público. Este objetivo poderia alcançar-se se se promovesse com afinco uma visão alternativa sobre o papel que os advogados devem cumprir em comunidades políticas em desenvolvimento, como as latino-americanas, e se evidenciam as consequências positivas que tem os núcleos para a consolidação de habilidades jurídicas necessárias para a atuação profissional competente. Reuniões com estudantes dos primeiros e últimos semestres, informar sobre as conquistas dos núcleos tanto nas faculdades como nos meio de comunicação, ou impulsionar campanhas de divulgação dentro das próprias faculdades para associar o trabalho socialmente responsável do advogado com o êxito profissional, são algumas estratégias que se poderia implementar para lograr os fins apontados.

Em quinta instância, criar ou fortalecer os vínculos formais e informais entre os que, em nível local e internacional, trabalham nos núcleos de prática jurídica de interesse jurídico. A Rede Latino-americana de Direito de Interesse Público, por exemplo, é um espaço privilegiado para alcançar este objetivo. Contudo, eventos acadêmicos menores no contexto nacional ou sub-regional também podem ser úteis para desenvolver redes de intercâmbio teórico e experimental em matéria de educação jurídica realizada nos núcleos da América Latina. Agora, não há de duvidar-se que para realizar este tipo de atividades, necessita-se da 
obtenção constante de recursos econômicos e de um esforço sistemático e continuado por manter aberta a comunicação entre os núcleos da região.

Em sexta e última instância, fomentar uma maior reflexão entre os que trabalham nas clínicas de maneira que se gere uma maior produção acadêmica que explique e analise sua tarefa. Sem a existência de um processo contínuo e sistemático de análise e avaliação do próprio trabalho, será muito difícil lograr que os núcleos de prática jurídica de interesse público se tornem um feito indiscutível de qualquer faculdade de direito da região. Sem a criação do conhecimento jurídico sobre o trabalho dos núcleos, será muito difícil pensar em como poderem ser mais efetivos na realização dos objetivos pedagógicos e de justiça social que busca este tipo de projetos. A criação de revistas nacionais, sub-regionais ou regionais sobre o ensino do direito, por exemplo, seria uma alternativa para alcançar este objetivo. A publicação de livros editados ou escritos por vários professores latino-americanos poder ser outra destas estratégias.

Os núcleos de prática jurídica de interesse público são instituições que têm feito raízes nas faculdades de direito latino-americanas. A oposição a este tipo de projeto, sem dúvidas, continuará sendo poderosa dentro e fora da academia. Não obstante, pareceria que estes questionamentos dificilmente teriam a possibilidade de fazê-los desaparecer. Para que este propósito não tenha nenhuma possibilidade de tornar-se realidade, os professores do núcleos devem materializar seus objetivos pedagógicos e de justiça social de maneira cada vez mais precisa e eficiente. De igual forma devem refletir crítica, sistemática e rigorosamente em torno de seu trabalho e articular e implementar estratégias que possam neutralizar ou debilitar os obstáculos que lhes impedem de fazê-lo apropriadamente.

\footnotetext{
${ }^{1}$ No texto original: “clínicas de derecho de interés público" (N.T.).

2 Traduzidas como "Núcleos de Prática Jurídica de Interesse Público” (N.T.).

${ }^{3} \mathrm{Na}$ versão original “Consultorio Jurídico” (N.T.).
} 